\title{
Evaluation of the genotoxic potential of the Hypericum brasiliense (Guttiferae) extract in mammalian cell system in vivo
}

\author{
Anderson Victorino Espósito ${ }^{1}$, Danielli Maria Vieira Pereira ${ }^{1}$, Leandro Machado Rocha ${ }^{2}$, José Carlos \\ Tavares Carvalho ${ }^{1}$ and Edson Luis Maistro ${ }^{1}$ \\ ${ }^{1}$ UNIFENAS, Instituto de Farmácia e Nutrição, Alfenas, MG, Brazil. \\ ${ }^{2}$ Universidade Federal Fluminense, Rio de Janeiro, RJ, Brazil.
}

\begin{abstract}
Plants of the genus Hypericum, long used in folk medicine, contain active compounds which present, anti-septic, diuretic, digestive, expectorant, vermifugal, anti-depressive and other properties. The possible clastogenic effect of a $H$. brasiliense extract was tested in vivo on the bone marrow cells of Wistar rats. The extract was administered by gavage at doses of 50,150 and $300 \mathrm{mg} / \mathrm{kg}$ body weight. Experimental and control animals were submitted to euthanasia $24 \mathrm{~h}$ after the treatment for micronucleus (MN) and chromosome preparations. H. brasiliense extract did not induce statistically significant increases in the average numbers of $\mathrm{MN}$ or chromosome aberrations in the test systems employed.
\end{abstract}

Key words: Hypericum brasiliense, micronucleus test, chromosome aberrations.

Received: March 4, 2004; Accepted: June 3, 2004.

\section{Introduction}

Herbs and botanical preparations are extensively used therapeutically in Brazil, the United States, India as well as other countries; in Europe they have been used for decades (Vogelzang, 2001). The genus Hypericum is represented by 350 species distributed throughout the world. Some species belonging to the Guttiferae family, may reach $12 \mathrm{~m}$; others remain at $0.5 \mathrm{~m}$ (Robson, 1977). Some of its therapeutic properties have been described, and include actions: antiseptic, digestive, vermifugal, expectorant, etc. (Corrêa, 1979). Mitchel and Rook (1979) described its action against vitiligo. $H$. perforatum has been intensively studied and used as an anti-depressive (Suzuki et al., 1984; Gupta and Moller, 2003). The analgesic and anti-depressive actions of Hypericum brasiliense have been recently investigated (Rieli-Mendes et al., 2002). In Brazil, H. brasiliense has become popularly known as "erva de São João".

Prior to this work, Hypericum perforatum was the only specie from the genus Hypericum whose mutagenic potential had been evaluated. The genotoxicity of a standardized aqueous ethanolic $H$. perforatum extract was verified in different in vivo and in vitro test systems of mammalian cells. This extract contained hypericin and hypericin-like substances as well as flavonoids, among

Send correspondence to Edson Luis Maistro. UNIFENAS, Instituto de Farmácia e Nutrição, 37130-000, Alfenas, MG, Brazil. E-mail address: edson.maistro@unifenas.br. which quercetin in particular, has generated wide controversy regarding its mutagenic action (Okpanyi et al., 1990). Both in-vitro and in vivo tests using mouse cells and bone marrow cells from the Chinese hamster yielded negative results, giving completely no indication of the mutagenic potential of these extracts (Okpanyi et al., 1990).

The potential therapeutic use of Hypericum brasiliense extract and the absence of any data on their mutagenicity in eukaryotes, led to the present study, undertaken to evaluate possible clastogenic effects of this extract in terms of the induction of micronuclei and chromosome aberrations, in Wistar rat bone marrow cells in vivo.

\section{Material and Methods}

\section{Plant material}

Plant material was collected in the mountainous region of the state of Rio de Janeiro, Brazil. A voucher specimen (n. 00237) has been deposited in the ICQBA, UNICAMP, Brazil. The extract was obtained from the leaves using as an extractor the solvent hexane, followed by ethanol percolation and standardized according to the technique described by Rocha et al. (1995, patent pending).

\section{Animals and assay procedures}

Experiments were carried out on six-week-old Wistar rats (Rattus norvegicus), weighing approximately $100 \mathrm{~g}$. The animals were acquired from the Biotery of the Univer- 
sity of Alfenas (UNIFENAS), kept in polyethylene boxes $(n=6)$, in a climate-controlled environment $\left(25 \pm 4{ }^{\circ} \mathrm{C}\right.$, $55 \pm 5 \%$ humidity), light/dark controlled every $12 \mathrm{~h}$ (7 a.m. to 7 p.m.). Food and water were available ad libitum. Rats were divided into experimental groups of six animals each (three males and three females). The Hypericum brasiliense extract was administered in a single dose of $0.5 \mathrm{~mL}$ by gavage at concentrations of 50,150 and $300 \mathrm{mg} / \mathrm{kg}$ body weight, chosen on the basis of the $\mathrm{LD}_{50}$ of $537 \mathrm{mg} / \mathrm{kg}$ as determined by Rieli-Mendes et al. (2002). The negative control group received distilled water and the positive control group received $30 \mathrm{mg}$ of cyclophosphamide $/ \mathrm{kg}$. Animals were injected intraperitoneally with $0.5 \mathrm{~mL}$ of $0.16 \%$ colchicine 90 min before euthanasia, which occurred $24 \mathrm{~h}$ after experimental treatment. Both femur bones were then excised and their bone marrow flushed into test tubes using a syringe. For the micronucleus $(\mathrm{MN})$ assay, the bone marrow cells were prepared as recommended by Schimid (1976). The slides were coded, fixed with methanol and stained by Giemsa solution. Two thousand polychromatic erythrocytes (PCE) from each animal were scored for $\mathrm{MN}$ presence. Bone marrow preparations for the analysis of chromosome aberrations in metaphase cells were obtained by the technique of Ford and Hamerton (1956). One-hundred metaphases per animal (600 metaphases per group) were analyzed in order to determine the number of chromosomal aberrations in a blind test. The chromosomal aberrations analyzed were gaps, breaks, deletions, fragments, rings and dicentric chromosomes. Gaps were not considered in the statistical analysis. The mitotic index (MI), was obtained by counting the number of mitotic cells in the 1000 cells analyzed per animal. The data obtained were submitted to the One-way analysis of variance test (ANOVA) and the Tukey-Kramer multiple comparison test using the GraphPad Instat ${ }^{\mathbb{B}}$ software (version 3.01). Results were considered statistically significant at $\alpha=0.05$.

\section{Results and Discussion}

Tables 1 and 2 summarize the results of the analysis of micronucleus and chromosome aberrations respectively, in bone marrow cells of Wistar rats following treatment with different concentrations of the $H$. brasiliense extract and controls.

Administration of $H$. brasiliense extract did not result in a increase in the average number of polychromatic erythrocytes with micronuclei (MNPCE) (Table 1). Comparisons between different dose groups showed no significant differences between MNPCE mean numbers (TukeyKramer test, $\mathrm{p}$ 0.05).

The MI values obtained from the analysis of 1000 cells/animal for a sample of 30 animals $(n=6 /$ group $)$ ranged from 1.7 to $3.8 \%$ (means) and statistical analysis by the Tukey-Kramer test showed no significant differences $(\mathrm{p}>0.05)$ between the different treatments with $H$. brasiliense extract, or between these treatments and their controls. These data indicate no cytotoxic effect of the $H$. brasiliense extract at the doses tested (Table 2).

The data obtained from 600 metaphases analysed per treatment (100 metaphase cells/animal), also showed that there were no statistically significant differences between the mean number of chromosome aberrations of treated groups and of the negative control. The most frequent types of aberrations of the treated groups were chromatid gaps, chromatid breaks and deletions.

The extract of the leaves and flowers of $\mathrm{H}$. brasiliense was characterized by Rocha et al. (1995), who found, three known phloroglucinols (japonicine $\mathrm{A}$, uliginosin $\mathrm{A}$ and isouliginosin B), a new phloroglucinol (hyperbrasiol A), and the flavonoids kaempferol, luteolin, quercitrin, isoquercitrin, hyperoside and guaijaverin. According to the authors, all four phloroglucinols presented antibacterial action against Bacilus subtilis. More recently, Rieli-Mendes et al. (2002), studying hydroalcoholic extracts from $H$. brasiliense and $H$. cordatum, observed that both species showed generalized depressant action on the central nervous system suggesting possible analgesic action.

A number of potentially positive health effects, including anti-cancer and anticarcinogenic effects, have been ascribed to the flavonoids, similar to that found in $H$. brasiliense extract, based on in vitro and in vivo studies

Table 1 - Mean of polychromatic erythrocytes with micronuclei (MNPCE) observed in bone marrow cells of female (F) and male (M) Wistar rats treated with a Hypericum brasiliense extract, and respective controls.

\begin{tabular}{|c|c|c|c|c|c|c|c|c|}
\hline \multirow[t]{2}{*}{ Treatments } & \multirow{2}{*}{$\begin{array}{l}\text { Dose } \\
\mathrm{mg} / \mathrm{kg}\end{array}$} & \multicolumn{6}{|c|}{ Number of MNPCE per animal } & \multirow{2}{*}{$\begin{array}{c}\text { MNPCE } \\
(\text { Mean } \pm \text { SEM })\end{array}$} \\
\hline & & $\mathrm{F}_{1}$ & $\mathrm{~F}_{2}$ & $\mathrm{~F}_{3}$ & $\mathrm{M}_{1}$ & $\mathrm{M}_{2}$ & $\mathrm{M}_{3}$ & \\
\hline Negative control (Water) & 0 & 9 & 10 & 9 & 10 & 11 & 8 & $9.50 \pm 0.43$ \\
\hline Hypericum extract & 50 & 9 & 10 & 7 & 9 & 8 & 10 & $8.83 \pm 0.48$ \\
\hline Hypericum extract & 150 & 9 & 10 & 9 & 8 & 9 & 9 & $9.00 \pm 0.25$ \\
\hline Hypericum extract & 300 & 9 & 11 & 12 & 9 & 14 & 11 & $11.00 \pm 0.77$ \\
\hline $\begin{array}{l}\text { Positive control } \\
\text { (Cyclophosphamide) }\end{array}$ & 30 & 29 & 23 & 22 & 27 & 25 & 25 & $25.17 * \pm 1.05$ \\
\hline
\end{tabular}

Two thousand cells were analyzed per animal, for a total of 12000 cells per group. SEM = standard error of the mean.

* Significantly different from negative control $(p<0.05)$. 
Table 2 - Mitotic Index (MI) and distribution of the different types of chromosomal aberrations (CA) observed in female (F) and male (M) Wistar rat bone marrow cells treated with a Hypericum brasiliense extract, and respective controls.

\begin{tabular}{|c|c|c|c|c|c|c|c|c|}
\hline \multirow[t]{3}{*}{ Treatments } & \multirow[t]{3}{*}{ Sex } & \multirow[t]{3}{*}{ MI (\%) } & \multicolumn{4}{|c|}{ Chromosomal aberrations } & \multirow[b]{3}{*}{$\mathrm{OA}$} & \multirow{3}{*}{$\begin{array}{c}\text { Total (CA) } \\
\text { without gaps }\end{array}$} \\
\hline & & & \multicolumn{2}{|c|}{ Gaps } & \multicolumn{2}{|c|}{ Breaks } & & \\
\hline & & & $\mathrm{C}$ & IC & $\mathrm{C}$ & IC & & \\
\hline Negative control & $\mathrm{F}_{1}$ & 3.4 & 4 & 0 & 3 & 1 & $1 \mathrm{del}$ & 5 \\
\hline \multirow[t]{6}{*}{ (Water) } & $\mathrm{F}_{2}$ & 2.2 & 3 & 0 & 1 & 0 & $2 \mathrm{del}$ & 3 \\
\hline & $\mathrm{F}_{3}$ & 3.8 & 0 & 1 & 1 & 1 & $3 \mathrm{del}$ & 5 \\
\hline & $\mathrm{M}_{1}$ & 2.0 & 1 & 1 & 1 & 0 & 0 & 1 \\
\hline & $\mathrm{M}_{2}$ & 3.2 & 1 & 2 & 2 & 0 & $3 \mathrm{del}$ & 5 \\
\hline & $\mathrm{M}_{3}$ & 2.8 & 1 & 0 & 1 & 0 & $3 \mathrm{del}$ & 4 \\
\hline & mean \pm SEM & $2.90 \pm 0.28$ & & & & & & $3.83 \pm 0.65$ \\
\hline H. brasiliense extract & $\mathrm{F}_{1}$ & 4.2 & 3 & 1 & 1 & 0 & $3 \mathrm{del} / 1 \mathrm{r}$ & 4 \\
\hline \multirow[t]{6}{*}{$(50 \mathrm{mg} / \mathrm{kg})$} & $\mathrm{F}_{2}$ & 2.4 & 1 & 0 & 1 & 1 & $3 \mathrm{del}$ & 5 \\
\hline & $\mathrm{F}_{3}$ & 5.2 & 1 & 0 & 1 & 0 & $1 \mathrm{del}$ & 2 \\
\hline & $\mathrm{M}_{1}$ & 5.5 & 6 & 3 & 3 & 2 & $4 \mathrm{f}$ & 9 \\
\hline & $\mathrm{M}_{2}$ & 3.3 & 2 & 0 & 2 & 0 & $2 \mathrm{f} / 1 \mathrm{dic}$ & 4 \\
\hline & $\mathrm{M}_{3}$ & 2.2 & 0 & 0 & 0 & 0 & $1 \mathrm{del} / 1 \mathrm{r}$ & 1 \\
\hline & mean $\pm \mathrm{SEM}$ & $3.80 \pm 0.57$ & & & & & & $4.16 \pm 1.13$ \\
\hline H. brasiliense extract & $\mathrm{F}_{1}$ & 2.1 & 4 & 0 & 0 & 0 & $1 \mathrm{del}$ & 1 \\
\hline \multirow[t]{6}{*}{$(150 \mathrm{mg} / \mathrm{kg})$} & $\mathrm{F}_{2}$ & 2.3 & 4 & 2 & 1 & 0 & 2del & 3 \\
\hline & $\mathrm{F}_{3}$ & 2.3 & 3 & 1 & 2 & 0 & $3 \mathrm{del}$ & 5 \\
\hline & $\mathrm{M}_{1}$ & 4.1 & 2 & 0 & 6 & 1 & $2 \mathrm{del}$ & 9 \\
\hline & $\mathrm{M}_{2}$ & 2.8 & 1 & 0 & 1 & 0 & $1 \mathrm{del}$ & 2 \\
\hline & $\mathrm{M}_{3}$ & 2.5 & 4 & 5 & 1 & 0 & 0 & 1 \\
\hline & mean \pm SEM & $2.68 \pm 0.29$ & & & & & & $3.50 \pm 1.25$ \\
\hline H. brasiliense extract & $\mathrm{F}_{1}$ & 2.8 & 4 & 0 & 3 & 0 & $2 \mathrm{del}$ & 5 \\
\hline \multirow[t]{6}{*}{$(300 \mathrm{mg} / \mathrm{kg})$} & $\mathrm{F}_{2}$ & 2.9 & 3 & 0 & 1 & 0 & $1 \mathrm{del}$ & 2 \\
\hline & $\mathrm{F}_{3}$ & 2.7 & 2 & 2 & 0 & 0 & $1 \mathrm{del}$ & 1 \\
\hline & $\mathrm{M}_{1}$ & 2.4 & 2 & 0 & 3 & 0 & $3 \mathrm{del}$ & 6 \\
\hline & $\mathrm{M}_{2}$ & 2.2 & 0 & 0 & 7 & 0 & $1 \mathrm{del}$ & 8 \\
\hline & $\mathrm{M}_{3}$ & 2.3 & 5 & 1 & 0 & 0 & $1 \mathrm{del}$ & 1 \\
\hline & mean \pm SEM & $2.55 \pm 0.11$ & & & & & & $3.83 \pm 1.19$ \\
\hline Positive control & $\mathrm{F}_{1}$ & 1.2 & 16 & 0 & 17 & 0 & $8 \mathrm{del}$ & 25 \\
\hline (Cyclophosphamide) & $\mathrm{F}_{2}$ & 1.0 & 8 & 1 & 13 & 1 & $8 \mathrm{del} / 1 \mathrm{r}$ & 22 \\
\hline \multirow[t]{5}{*}{$(30 \mathrm{mg} / \mathrm{kg})$} & $\mathrm{F}_{3}$ & 1.4 & 9 & 0 & 8 & 0 & 9del & 17 \\
\hline & $\mathrm{M}_{1}$ & 2.7 & 9 & 1 & 12 & 1 & $7 \mathrm{del}$ & 20 \\
\hline & $\mathrm{M}_{2}$ & 2.0 & 10 & 3 & 9 & 1 & $14 \mathrm{del}$ & 24 \\
\hline & $\mathrm{M}_{3}$ & 2.0 & 9 & 1 & 12 & 0 & $8 \mathrm{del}$ & 20 \\
\hline & mean \pm SEM & $1.71 \pm 0.25$ & & & & & & $21.33 * \pm 1.20$ \\
\hline
\end{tabular}

One hundred cells were analyzed per animal, for a total of 600 cells per treatment. C, Chromatid-type; IC, isochromatid-type; OA, other aberrations: $\mathrm{del}=$ deletion; $\mathrm{f}=$ fragments; $\mathrm{r}=$ ring; dic $=$ dicentric; $\mathrm{SEM}=$ standard error of the mean. * Significantly different from negative control $(\mathrm{p}<0.001)$.

both in humans and in animals (Cody et al., 1986; 1988; Sudheesh et al., 1999). Chacon et al. (2002) observed an absence of genotoxic effects of a standardized extract of the medicinal plant Solanum melongena, rich in flavonoids, on peripheral blood and bone marrow cells of Wistar rats and Ferreira et al. (2003) related that the same extract presented protective effects against chromosomal aberrations induced by doxorubicin in Wistar rat cells.

The genotoxic effect of $H$. brasiliense extract on the bone marrow of Wistar rats was studied for the first time in the present work. The results indicated that the mixture of the compounds found in these extract did not induce a sig- 
nificant increase in the mean number of cells with micronuclei or chromosome aberrations when given at the doses of 50,150 and $300 \mathrm{mg} / \mathrm{kg}$ body weight. Although the results of the present study do not preclude the therapeutic consumption of $H$. brasiliense extract, caution regarding the indiscriminate use by the public of these, and other medicinal plants, continues to be necessary.

\section{Acknowledgments}

This investigation was supported by FAPEMIG (Rede Mineira de Ensaios Toxicológicos e Farmacológicos de Produtos Terapêuticos, EDT - 1879/02), CNPq and UNIFENAS.

\section{References}

Cody V, Middleton E and Harborne JB (1986) Plant Flavonoids in Biology and Medicine: Biochemical, Pharmacological and Structure Activity Relationships. Alan R. Liss, New York.

Cody V, Middleton E, Harborne JB and Bertz A (1988) Plant Flavonoids in Biology and Medicine II: Biochemical, Cellular and Medicinal Properties. Alan R. Liss, New York.

Corrêa MP (1979) Dicionário das Plantas Úteis do Brasil e das Exóticas Cultivadas. Ministério da Agricultura, Rio de Janeiro, Brazil.

Chacon DR, Dalla-Libera AN, Cintra DEC, Carvalho JCT, Oliveira GA and Maistro EL (2002) Absence of genotoxic and antigenotoxic effects of a standardized extract of the medicinal plant Solanum melongena on peripheral blood and bone marrow cells of Wistar rats. Cytologia 67:417-422.

Ferreira L, Carvalho JCT and Maistro EL (2003) Standardized Solanum melongena extract presents protective effects against chromosomal aberrations induced by Doxorubicin in Wistar rat bone marrow cells. Cytologia 68(2):177-181.
Ford CE and Hamerton JL (1956) A colchicine, hypotonic citrate, squash sequence for mammalian chromosomes. Stain Technol 31:247-251.

Gupta RK and Moller HJ (2003) St. John's Wort. An option for the primary care treatment of depressive patients. Eur Arch Psychiatry Clin Neurosci 253(3):140-148.

Mitchell JC and Rook A (1979) Botanical Dermatology. Greenglass, Vancouver, pp 787.

Okpanyi SN, Lidzba H, Scholl BC and Miltenburger HG (1990) Genotoxicity of a standardized Hypericum extract. Arzneimittelforschung 40(8):851-855.

Rieli-Mendes F, Mattei R and Carlini ELA (2002) Activity of Hypericum brasiliense and Hypericum cordatum on the central nervous system in rodents. Fitoterapia 73(6):462-471.

Robson NKB (1977) Studies in the genus Hypericum L. (Guttiferae). Bull Br Mus Nat Hist Bot 5:291-355.

Rocha L, Marston A, Potterat O, Kaplan MA, Stoeckli-Evans H and Hostettmann K (1995) Antibacterial phloroglucinols and flavonoids from Hypericum brasiliense. Phytochemistry 40(5):1447-1452.

Schmid W (1976) The micronucleous test for cytogenetic analysis. In: A. Hollaender (ed) Chemical Mutagenesis, Principles and Methods for their Detection. v. 4. Plenum Press, New York, pp 31-53.

Sudheesh S, Sandhya C, Koshy AS and Vijayalakshmi NR (1999) Antioxidant activity of flavonoids from Solanum melongena. Phytotherapy Research 13:393-396.

Suzuki O, Katsumata Y, Oya M, Bladt S and Wagner H (1984) Inhibition of monoamine oxidase by Hypericum. Planta Med 50:272-274.

Vogelzang JL (2001) What you need to know about dietary supplements. Home Healthe Nurse 19(1):50-52.

Associate Editor: Catarina S. Takahashi 